\title{
Radiometric Study in the Itaboraí Region, Brazil
}

\author{
Hans Schmidt Santos' ${ }^{1}$, Luíza Viênna Rangel Peixoto ${ }^{2}$ \\ ${ }^{1}$ Department of Research and Extension, Faculdade Salesiana Maria Auxiliadora, Macaé, Brasil \\ ${ }^{2}$ Chemical Engineering College, Faculdade Salesiana Maria Auxiliadora, Macaé, Brasil \\ Email: hans@on.br, wishlier@hotmail.com
}

Received 1 July 2014; revised 25 August 2014; accepted 28 September 2014

Copyright (C) 2014 by authors and OALib.

This work is licensed under the Creative Commons Attribution International License (CC BY). http://creativecommons.org/licenses/by/4.0/

(c) (i) Open Access

\begin{abstract}
This current paper discusses an application of the aerial radiometric method in the Itaboraí Region, located in Rio de Janeiro State, Brazil. Radiometric data acquired by aircraft registered in counts per second of potassium, thorium and uranium channels were processed generating radiometric maps of the entire region. The generated maps provide important information regarding the superficial geology. At last, all the radiometric information gained is correlated with geological and topographical knowledge of the Itaboraí Region.
\end{abstract}

\section{Keywords}

\author{
Aerial Radiometry, Potassium, Uranium and Thorium, Itaboraí Region
}

Subject Areas: Chemical Engineering \& Technology, Geochemistry, Geology, Geophysics

\section{Introduction}

Several applications are derived from the natural radioactivity of the chemical elements. Among the radioactive emissions, the gamma emission being a detectable electromagnetic wave at large distances has a special application in radiometric method. In this method, large areas can be investigated as for its shallow geological heritage, by detecting the radioactivity emanated from the constituent rocks from the soil and underground. In the Itaboraí Region, it stood out the São José do Itaboraí Basin which was the scene of exploitations of limestone for many decades. After finding large amount of fossil, it is today an important paleontological park in the region. Aeroradiometric data referred to Itaboraí covering the basin are processed and the main results can be used for better understanding of the regional geology. Moreover, it can serve as the basis for future geological, environmental and geochemical studies in the region.

\section{Characteristics of the Studied Area}

The Itaboraí Region is located in the metropolitan region of Rio de Janeiro state, in an area of coastal lowland with 
margins in the Guanabara Bay (Figure 1). The county covers an area of $430.4 \mathrm{~km}^{2}$. The neighboring counties are Guapimirim, Tanguá, Cachoeiras de Macacu, Maricá and São Gonçalo [1].

The region of Itaboraí presents a varied relief and low altitudes. The topography of the region is shown in Figure 2.

Its highest elevations are found in the Barbosão Sierra located to the east on the border with Tanguá County, the Lagarto Sierra and the Cassorotiba do Sul Sierra, bordering the Maricá County. In other parts of the county predominate plains which have rivers that converge to the Guanabara Bay. In the plains and mountains, there is a soft, wavy relief, with small hills which few times exceed 50 meters of altitude. The vegetation of the county is mainly composed of pastures, hillside forest, swamps and marshes (Figure 3) [2].

The oldest Brazilian paleontological site is located in the sedimentary basin of São José do Itaboraí in Itaboraí. The São José do Itaboraí Basin is considered one of the smallest known sedimentary basins in Brazil. This basin stands out because of its diverse lithology and its rich fossil content [3]. The sediments of the basin include clasts of angular fragments of quartz and feldspar, and pieces of rocks, in pelitic carbonate matrix, containing abundance of gastropod fossils. The crystalline basement of the basin consists of igneous and metamorphic rocks such as gneisses, migmatites and granites [4].

The geology of the region of the county of Itaboraí is shown on Figure 4.

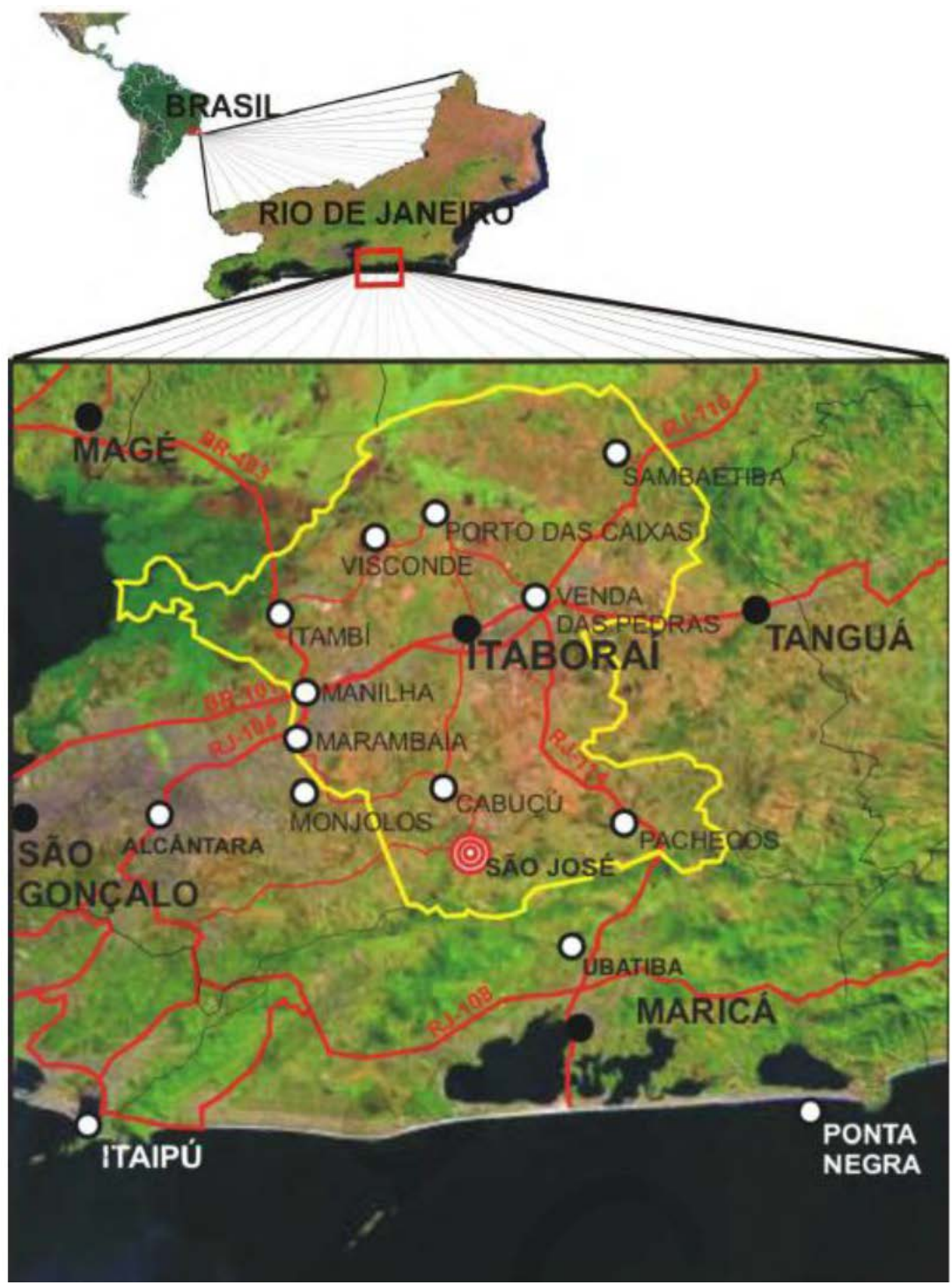

Figure 1. Localization of Itaboraí County in Rio de Janeiro, Brazil [1]. 


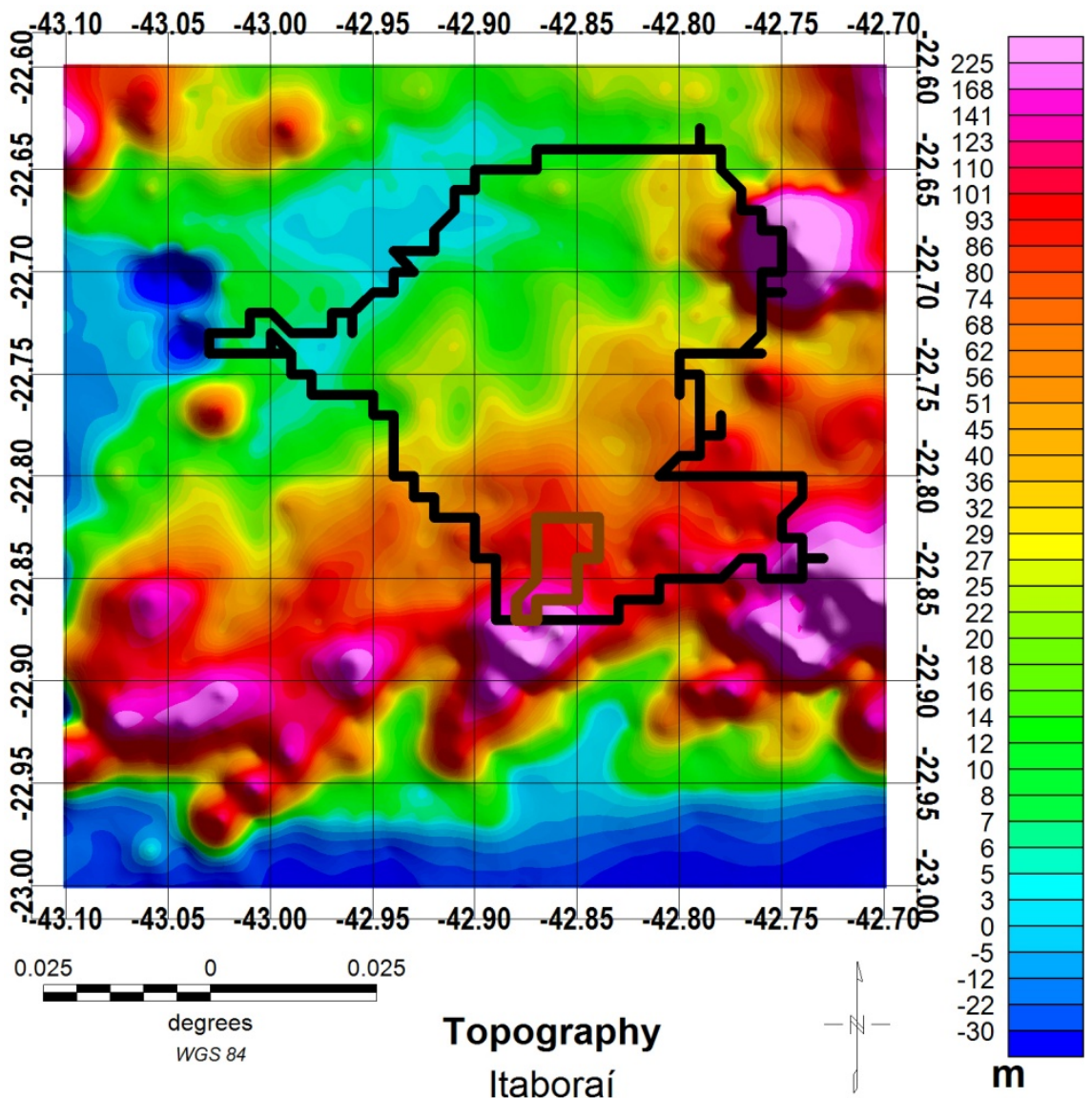

Figure 2. Topographic map of Itaboraí and surroundings.

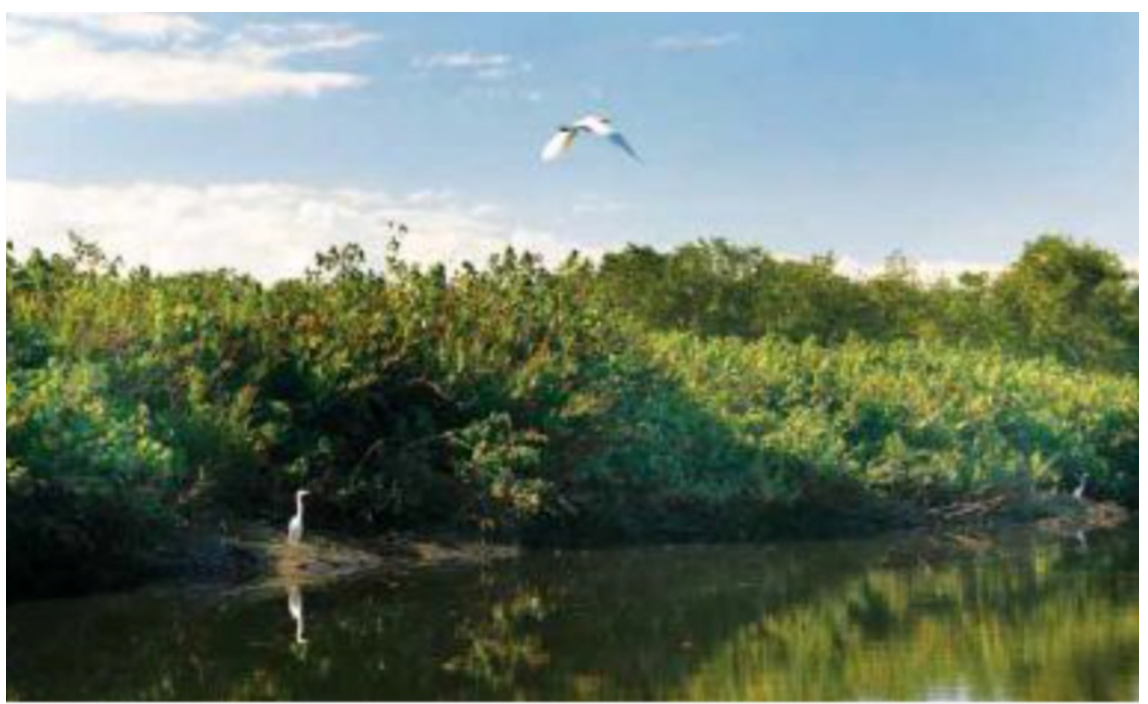

Figure 3. Typical mangroves of the Itaboraí Region [2].

The whole Itaboraí County is covered by aeroradiometric surveys made by a Bandeirante aircraft with sampling intervals of $100 \mathrm{~m}, 1 \mathrm{~km}$ spaced profiles and measurement lines in the N-S direction. The gamma spectrometer used in the survey was the Geometrics GR-800A with sodium iodide crystals activated by thallium and volume of 3072 cubic inches. These collected data were used in this work. 


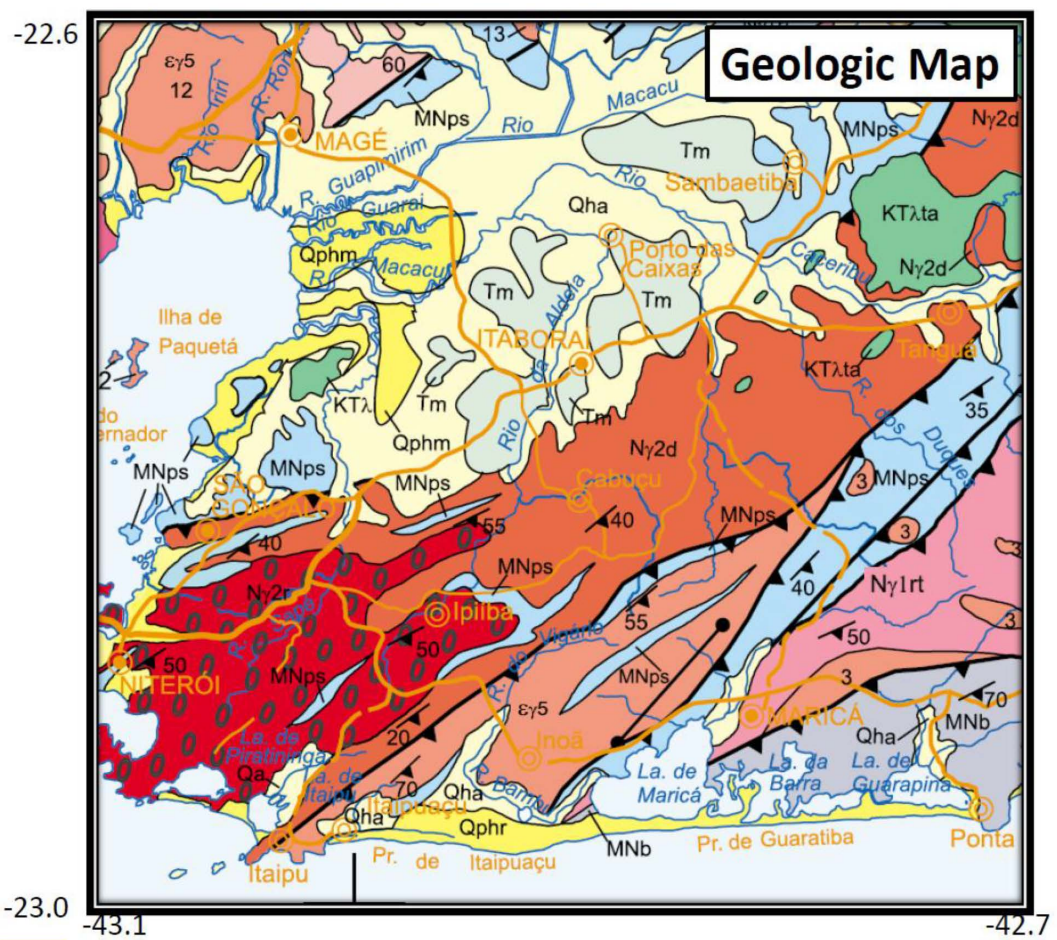

(a)

Qha Colluvial-Alluvial Deposit Fluvial and fluviomarine deposits of clay, silt and sand including talus-related gravel beds, and reworked lacustrine and mangrove sediments.

Qphm Marine and Fluviomarine Deposit Siltic-clayey-sandy fluviomarine deposits rich in organic matter, encompassing Recent to sub-Recent shorelines and mangroves as well.

Qphr Sandbar Deposit Structureless deposits of homogeneous, loose quartz sandbars, constituting Recent dunes fields (aeolian deposits)

Rio de Janeiro Suite Foliated granitoids and gneisses characterized as crustal derivation (S-type granites)

Ny2d Desengano Suite S-type garnet-muscovite-biotite bearing granite, with coarse-grained granoblastic to porphyritic (augen) textures and strong strike-slip related solid-state fabrics. Locally garnet-orthopyroxene bearing charnockitic domains and patches are found. Xenoliths and restites of partly melted paragneiss occur throughout (injection migmatite facies).

Ny2ss Santo Aleixo Unit Marginal facies of Serra dos Órgãos Batholith comprising hornblendegarnet-biotite bearing grandiorite, rich in partly melted and assimilated paragneissic countryrock xenoliths and late S-type leucogranite intrusion (injection migmatite facies).

Ny1r RioNegro Complex Biotite-hornblende TTG, coarse-grained, banded orthogneiss with strong thrust-related planar fabrics and recrystallised porphyriticto augen textures. Deformed metagabbro and metadiorite (amphibolite) intercalations occur locally.

MNos Paraíba do Sul Complex Garnet-biotite-sillimanite quartzofeldspathic gneiss (metagreywacke), locally bearing graphite-rich domains; widespread in situ and injected,pockets and veins of granitic leucossome. Abundant interleaved calc-silicate gneiss and quartzite lenses. Cordierite-sillimanite-graphite bearing varieties(kinzigite) have transitive contacts wiyh garnet-biotite gneiss. Graphitic schist bands are common; Metacarbonatic calc-silicate rock and quartzite, locally interleaved. Turbiditic structures very locally preserved in low-strain domains.

MNb Búzios Complex kyanite-sillimanite-garnet-biotite quartzofeldspatic gneiss and schist interleaved with garnet amphibolite and calc-silicate gneiss. Partial melting garnet-bearing leucosomes are ubiquitous. In low-strain domains turbitic structures are preserved.

KT入 Tanguá Alkaline Massif Syenites, nepheline syenites, foyaites, fonolites, trachytes, tinguaites, pulaskites, umptekitites, fenites.

E 5 Post-tectonic granitoids I-type (Hornblende)-biotite granitoids.Occur as tabular bodies, dykes, stocks and small batholiths crosscutting the country-rocks.

'Tm Macacu Formation Succession of rounded sandstone layers.

Figure 4. (a) Geolologic map of the Itaboraí County and surroundings [5]. (b) Legend of the Itaboraí gologic map [5]. 


\section{Methods}

The radiometric method consists in the detection of nuclear emissions from rocks which contain radioactive minerals. In case, it is detected gamma radiation (electromagnetic wave) using a scintillation counter or Geiger counter. These radiometric instruments were first developed for the detection of uranium, but soon appeared other important applications. The method is widely used for geological mapping, being useful to identify lithology by the radioactive contents [6].

\subsection{Gamma Radiation Sources}

Gamma radiation has a discrete energy contained in a photon that is characteristic of the emitting material. This is the basis of the gamma spectrometry: by measuring the energy of the photons, one can determine the source of radiation [7]. Potassium $\left({ }^{40} \mathrm{~K}\right)$, Uranium $\left({ }^{238} \mathrm{U},{ }^{235} \mathrm{U}\right.$ and decay series elements) and Thorium $\left({ }^{232} \mathrm{Th}\right.$ and decay series elements) are the only radioisotopes which emit gamma radiation with intensity large enough to be used in the mapping of gamma radiation. The detection is performed through specific windows (Figure 5) [8].

All radiation that is not derived from geological sources is called background radiation and it needs to be removed in data processing. There are three major sources of background radiation: atmospheric radiation, cosmic radiation, and the instrumental radiation. The largest source of background radiation is atmospheric radon ( $\left.{ }^{222} \mathrm{Rn}\right)$ and its decay series elements. This undesired effect occurs because the ${ }^{222} \mathrm{Rn}$ can get out of the rocks and accumulate in the atmosphere. Its decay series elements $\left({ }^{214} \mathrm{Bi}\right.$ e $\left.{ }^{214} \mathrm{~Pb}\right)$ can be added to aerosols and dust. But the instrumental background radiation is related to radiation arising from traces of $\mathrm{K}$, $\mathrm{U}$ and Th in the detectors and neighboring equipment, aircraft or vehicle. This background radiation is taken as constant [7].

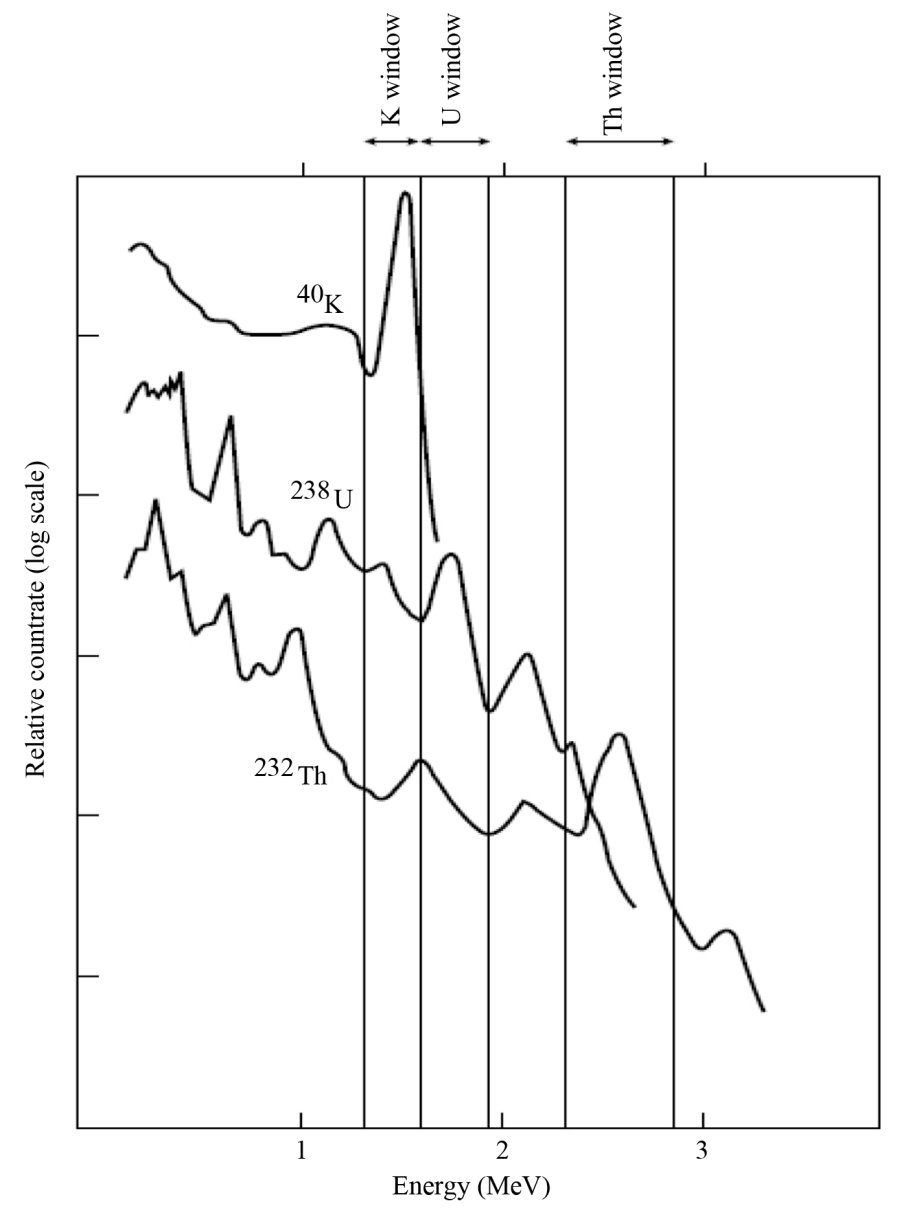

Figure 5. Typical power windows of Uranium, Thorium and Potassium detection [8]. 


\subsection{Geochemistry of Radionuclides}

Potassium (K), Uranium (U) and Thorium (Th) are primarily responsible for the natural radioactivity of the rocks. They are lithophile and are mainly concentrated in acid igneous rocks [9].

Potassium $\left({ }^{40} \mathrm{~K}\right)$ is the most abundant of the three natural radionuclides. The main sources are the potassium are feldspars, muscovites and biotites. The Uranium $\left({ }^{238} \mathrm{U}\right)$ and Thorium $\left({ }^{232} \mathrm{Th}\right)$ can be found in small amounts in minerals such as quartz, feldspar and higher concentrations of minerals as the zircon, epidote, apatite and monazite [9]. In igneous rocks, radioactivity can vary greatly due to the chemical, mineralogical, petrographic and structural features. Table 1 summarizes the major radioactive minerals [8].

\subsection{Acquisition and Corrections of Aerial Radiometric Data}

The gamma radiometric surveys can be terrestrial or aerial. In the terrestrial surveys, the spectrometer is positioned on the ground or on the surface which we want to perform the measurement. In airborne surveys, the equipment stays in the interior of an aircraft which is usually a plane. The basic difference between these methods is the represented area. The flying height and the spacing between flight lines determines the resolution of the survey. The spacing of flight lines are normally about $1-2 \mathrm{~km}$ on a measurement density on each line around 70 $100 \mathrm{~m} \mathrm{[10].} \mathrm{In} \mathrm{the} \mathrm{present} \mathrm{study,} \mathrm{the} \mathrm{gamma} \mathrm{radiometric} \mathrm{surveys} \mathrm{was} \mathrm{aerial} \mathrm{mode} \mathrm{and} \mathrm{the} \mathrm{unit} \mathrm{used} \mathrm{to} \mathrm{measure} \mathrm{the}$ radiation activity was counts per second (cps).

Some corrections and tests need to be applied after the acquisition of aero radiometric data before proceeding to the interpretation of the results. The Low Level test performed for correction of radiometric data is also known as repeatability line. In this case, a measurement ramp needs to be created, usually in an airport runway where the aircraft flies in typical heights of exploration that are around $100 \mathrm{~m}$, then performing collections for around 2 minutes or $10 \mathrm{~km}$ measurements. Because the test is always performed on the same ramp, it generates a standard of radiometric measurements for the diurnal variation correction. The High Level test is also called calibration test. It is kept a direction of flight to collect measurements for about 3 minutes at a height of approximately $800 \mathrm{~m}$. In this case, it is not necessary that the ramp measure is always the same because we believe that the data in soil does not interfere with the measurements. The Background test is repeated daily. In this test, environment radiometric measurements are performed. This interference is also known as background measures. In addition to these corrections, it may be cited the Compton Effect correction in which the electromagnetic wave undergoes a scattering, increasing its wavelength and reducing the photon energy [11].

\section{Processing and Results}

In the first step, data from an area spanning Itaboraí (black contour) and also the vicinity of São José de Itaboraí Basin (brown contour) were processed to provide a regional study. The raw data received routine corrections from

Table 1. Radioactive mineral and their occurrences [8].

\begin{tabular}{|c|c|c|c|c|c|}
\hline \multicolumn{6}{|c|}{ Table of minerals and their occurrence } \\
\hline \multicolumn{2}{|c|}{ Potassium } & \multicolumn{2}{|c|}{ Thorium } & \multicolumn{2}{|c|}{ Uranium } \\
\hline Mineral & Occurrence & Mineral & Occurrence & Mineral & Occurrence \\
\hline $\begin{array}{l}\text { Orthoclase and } \\
\text { microcline feldspars } \\
{\left[\mathrm{KAlSi}_{3} \mathrm{O}_{8}\right]}\end{array}$ & $\begin{array}{l}\text { Main constituents in } \\
\text { acid igneous rocks } \\
\text { and pegmatites }\end{array}$ & $\begin{array}{l}\text { Monazite } \\
{\left[\mathrm{ThO}_{2}+\text { rare earth }\right.} \\
\text { phosphate }]\end{array}$ & $\begin{array}{l}\text { Granites, } \\
\text { pegmatites, gneiss }\end{array}$ & $\begin{array}{l}\text { Uraninite [oxide of } \mathrm{U} \text {, } \\
\mathrm{Pb}, \mathrm{Ra}+\mathrm{TH}, \\
\text { rare earths] }\end{array}$ & $\begin{array}{l}\text { Granites, pegmatites } \\
\text { and with vein deposits } \\
\text { of } \mathrm{Ag}, \mathrm{Pb}, \mathrm{Cu} \text {, etc. }\end{array}$ \\
\hline $\begin{array}{l}\text { Muscovite } \\
{\left[\mathrm{H}_{2} \mathrm{KAl}\left(\mathrm{SiO}_{4}\right)_{3}\right]}\end{array}$ & $\begin{array}{l}\text { Main constituents in } \\
\text { acid igneous rocks } \\
\text { and pegmatites }\end{array}$ & $\begin{array}{l}\text { Thorianite } \\
{\left[(\mathrm{Th}, \mathrm{U}) \mathrm{O}_{2}\right]}\end{array}$ & $\begin{array}{l}\text { Granites, } \\
\text { pegmatites, } \\
\text { placers }\end{array}$ & $\begin{array}{l}\text { Carnotite } \\
{\left[\mathrm{K}_{2} \mathrm{O} \cdot 2 \mathrm{UO}_{3} \cdot \mathrm{V}_{2} \mathrm{O}_{5} \cdot 2 \mathrm{H}_{2} \mathrm{O}\right]}\end{array}$ & Sandstones \\
\hline $\begin{array}{l}\text { Alunite } \\
{\left[\mathrm{K}_{2} \mathrm{Al}_{6}(\mathrm{OH})_{12} \mathrm{SiO}_{4}\right]}\end{array}$ & $\begin{array}{l}\text { Alteration in acid } \\
\text { volcanics }\end{array}$ & $\begin{array}{l}\text { Thorire, uranothorite } \\
{\left[\mathrm{ThSiO}_{4}+\mathrm{U}\right]}\end{array}$ & $\begin{array}{l}\text { Granites, } \\
\text { pegmatites, placers }\end{array}$ & $\begin{array}{l}\text { Gummite } \\
\text { [uraninite alteration] }\end{array}$ & $\begin{array}{l}\text { Associated with } \\
\text { uraninite }\end{array}$ \\
\hline $\begin{array}{l}\text { Sylvite, carnallite } \\
{\left[\mathrm{KCl}, \mathrm{MgCl}_{2} \cdot 6 \mathrm{H}_{2} \mathrm{O}\right]}\end{array}$ & $\begin{array}{l}\text { Saline deposits in } \\
\text { sediments }\end{array}$ & & & & \\
\hline
\end{tabular}


the radiometric method as the corrections of height, compton effect, background and also the application of microleveling (Butterworth filter). Through the technique of minimum curvature with cells of $250 \mathrm{~m}$, the count maps were made to the potassium (Figure 6), thorium (Figure 7) and uranium (Figure 8). After that, they were associated with the geological map (Figure 4).

The higher potassium counts are found along the $\mathrm{N} \gamma 1 \mathrm{rt}$ unit (Rio Negro Complex) associated with gneisses that are rich rocks in potassic feldspar and in the $\mathrm{N} \gamma 2 \mathrm{r}$ unit (Rio de Janeiro Suite) associated with granitic and gneisses present. The lowest scores of potassium show regions of sediments and mangroves present in the Qha (Colluvial Alluvial Deposit) and Tm (Macacu Formation) units.

The highest Thorium counts are associated with granites of the $\mathrm{N} \gamma 2 \mathrm{r}$ unit (Rio de Janeiro Suite). The Surui Granite (unit $\varepsilon \gamma 5$ - 12) in the northwestern region of the map is highlighted with a large Thorium count. The lowest scores of Thorium also denounce the regions of sediments and mangroves present in the Qha (ColluvialAlluvial Deposit) and Tm (Macacu Formation) units.

There are large uranium counts in the KT $\lambda$ unit (Tanguá Alkaline Massif), and in the granites of the N $\gamma 2 \mathrm{r}$ unit (Desengano Suite), besides the Surui Granite (Post-Tectonic Granitoids- $\varepsilon \gamma 5$ ) which is also in evidence. Lower scores are associated with areas of mangroves and a portion of the $\mathrm{N} \gamma 2 \mathrm{r}$ unit (Rio de Janeiro Suite).

Also the map of total count was made (Figure 9). The map allows to delineate some important units when compared to the topographic map (Figure 2) and geological map (Figure 4).

The map of total count can highlight some important geological units in the region. First, the map is able to highlight the continent in relation to the sea and the Guanabara Bay that have virtually zero counts. On the continent, the lowest scores are located in the central and northern region and they are associated with fluvial and fluvial-marine deposits, lacustrine sediments and mangroves of the Qha unit (Colluvial-Alluvial Deposit). The sandy sediments of the Tm unit (Macacu Formation) are also featured as a low count towards your vicinity. Very low counts are also associated with Qphm unit (marine and fluvial-marine deposits) that encompass the current lines of actual and old beaches, and mangroves located around Guanabara Bay and along the Itapuaçu Beach and Guaratiba Beach. The highest scores are in the region associated with granitoids and gneisses of the $\mathrm{N} \gamma 2 \mathrm{r}$ unit (Rio de Janeiro Suite), the granites of the N $\gamma 2 \mathrm{~d}$ unit (Desengano Suite) and garnets and gneisses of the MNPS unit (Paraíba do Sul Complex).

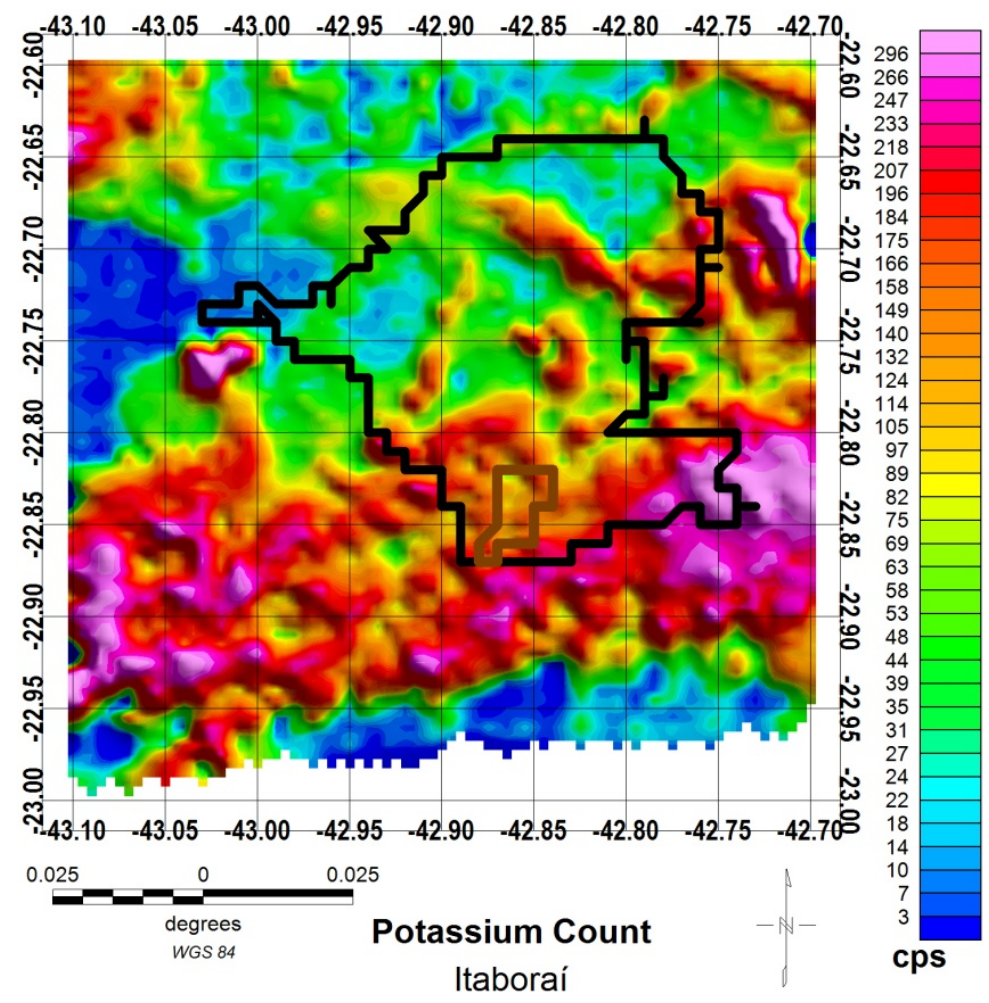

Figure 6. Count map of corrected Potassium in the Itaboraí Region. 


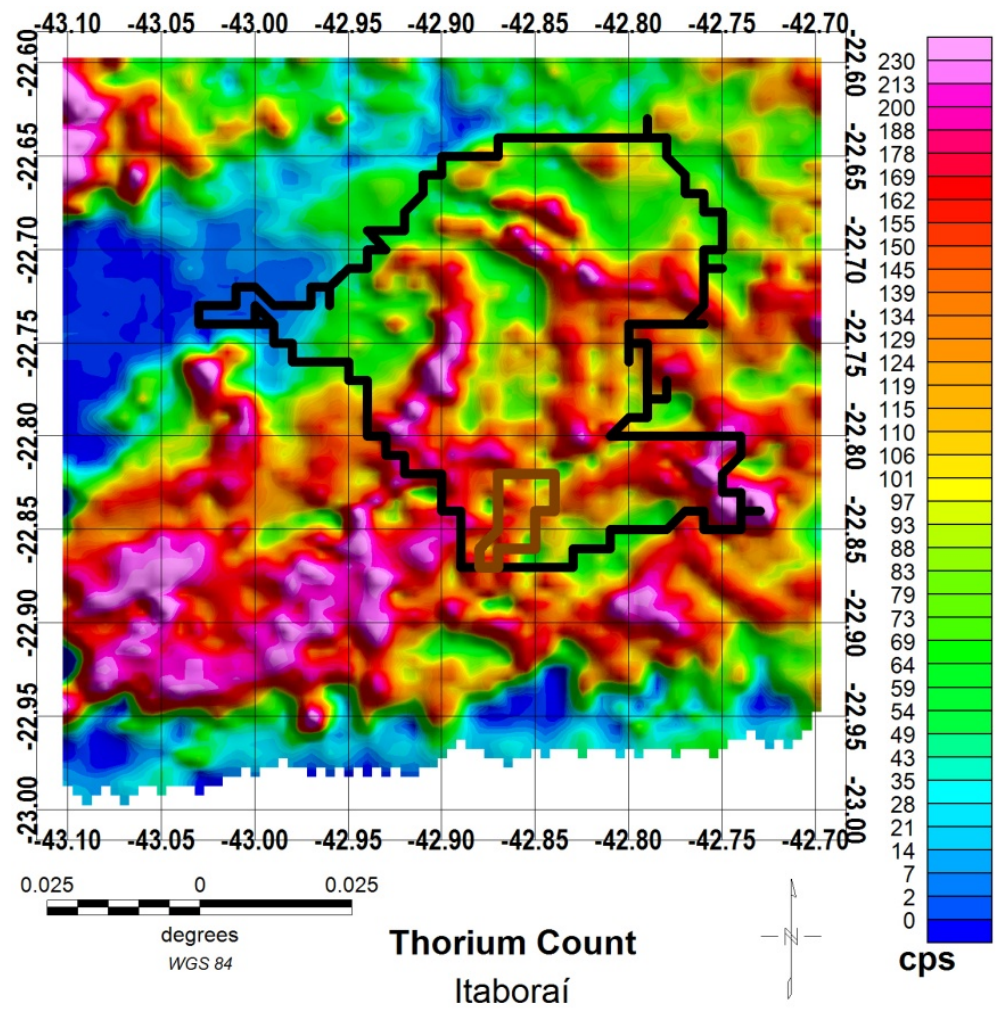

Figure 7. Count map of corrected Thorium in the Itaboraí Region.

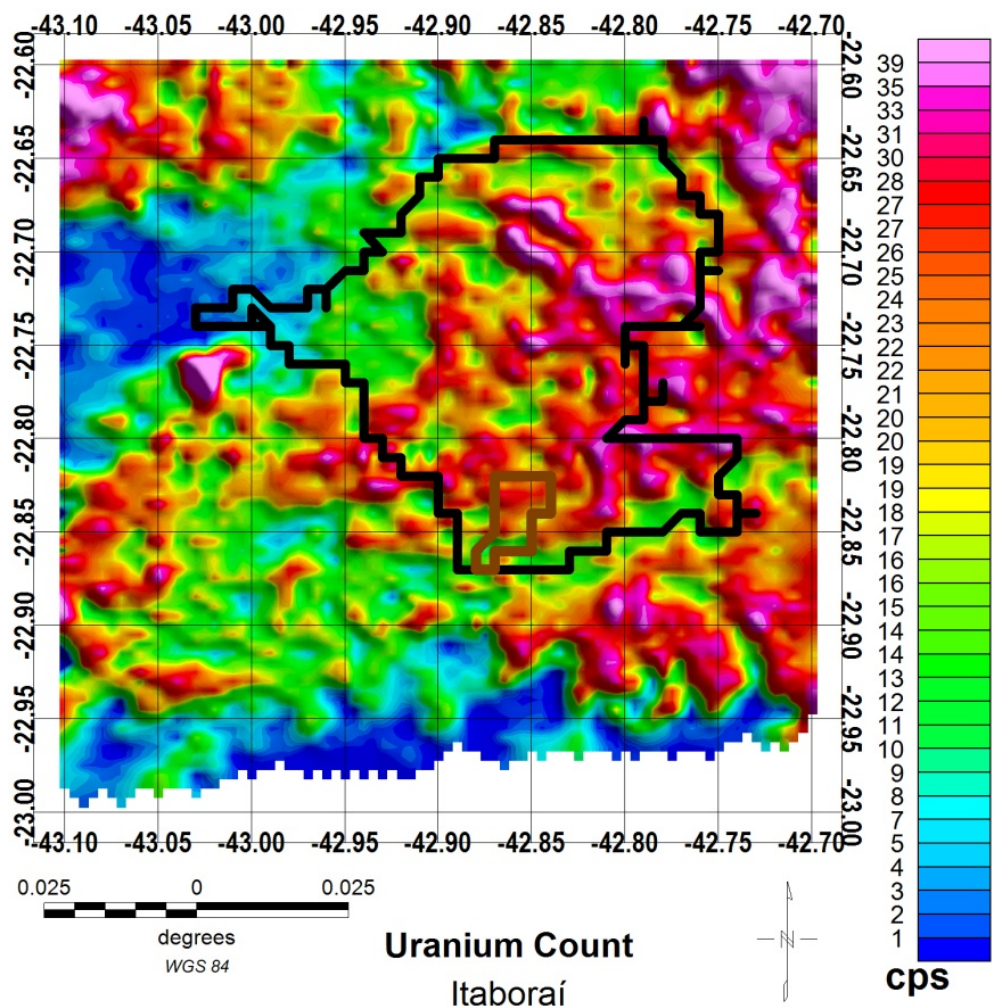

Figure 8. Count map of corrected Uranium in the Itaboraí Region. 


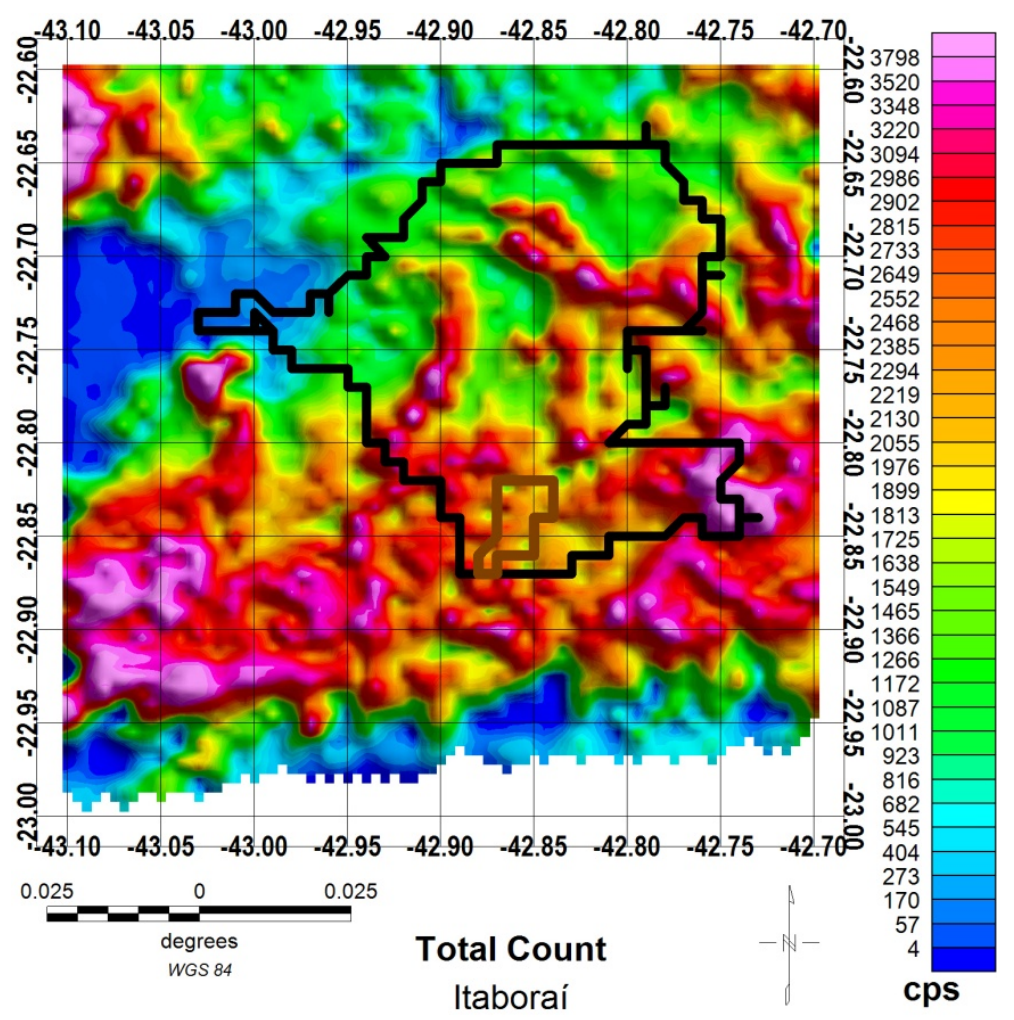

Figure 9. Total count map of the Itaboraí Region.

\section{Conclusion}

The count maps of the Itaboraí County helped to highlight the main geological structures in the region. In general, it is possible to make good differentiation between regions dominated by sediments and mangroves with low counts of other regions mainly rich with granites and gneisses. The area around the São José do Itaboraí Basin showed intermediate scores due to the gneisses and granites surrounding the limestone region of the basin. The comparison between the topographic maps (Figure 2) and the total counts maps (Figure 9) shows that the regions of highest altitude in general are also higher overall scores. This is because the lower regions are dominated by salt marshes, mangroves and sediment leading to a much lower score. It is recommended for future studies a reprocessing of these data by converting the counts (cps) to K\%, eTh and eU, which could bring more useful information to the knowledge of the regional geology.

\section{Acknowledgements}

The authors thank the reviewers for their valuable recommendations. In addition, the authors would like to express their thanks to the Research and Extension Coordinator Rodrigo S. Melo and the Chemical Engineering Coordinator Warlley Ligório Antunes from Faculdade Salesiana Maria Auxiliadora for trusting and supporting the work.

\section{References}

[1] Garcia, M.A. (2008) Análise Ambiental por Geoprocessamento do Parque Paleontológico de São José de Itaboraí, Município de Itaboraí (RJ): Uma Contribuição ao Turístico Científico. Graduation Thesis, UFRJ, Rio de Janeiro.

[2] Teixeira, A., Abrahão, J., Gonzaga, K.V.P., Kranz, P. and Albuquerque, T.F. (2012) Agenda 21 Itaboraí.

[3] Baptista, A.C.S. (2009) Reavaliação da evolução deposicional da Bacia de São José de Itaboraí com base em dados geológicos e geofísicos Universidade do Estado do Rio de Janeiro Centro de Tecnologia e Ciências Faculdade de Geologia.

[4] Meneses, R.M.X. (2009) Levantamento por Eletrorresistividade na Bacia de São José de Itaboraí. Graduation Thesis, 
UFRJ, Rio de Janeiro.

[5] Silva, L.C. and Cunha, H.C.S. (2001) Geologia do Estado do Rio de Janeiro: Texto explicativo do mapa geológico do Estado do Rio de Janeiro. $2^{a}$ edição revista em 2001. CPRM, Brasília.

[6] Ernesto, M. and Ussami, N. (2002) Introdução à Geofísica. Departamento de Geofísica IAG/USP.

[7] Silva, J.R.S. (2007) Estudo do Levantamento Aerogeofísico do Estado do Rio de Janeiro na Região dos Lagos. Ph.D. Thesis, Observatório Nacional, Rio de Janeiro.

[8] Kearey, P., Brooks, M. and Hill, I. (2002) An Introduction to Geophysical Exploration. 3rd Edition, Blackwell Science Ltd., Oxford, 281 p.

[9] Vasconcellos, R.M., Metello, M.J., Motta, A.C. and Gomes, R.D. (1994) Geofísica em Levantamentos Geológicos. CPRM, Rio de Janeiro, 165.

[10] Nascimento, L.S. (2003) Análise de Dados de Espectrometria-Gama Aérea e de Sensoriamento Remoto do Estado do Rio de Janeiro por Redes Neurais Artificiais. Aplicação ao Mapeamento Geológico Digital. Rio de Janeiro.

[11] Guimarães, S.N.P. (2009) Avanços recentes na determinação das estruturas geológicas em subsuperfície da Província Uranifera Lagoa Real (BA) a partir de dados aerogeofísicos. Observatório Nacional. Rio de Janeiro. 